\title{
The Expansion and Roles of Private Tutoring in India: From Supplementation to Supplantation
}

\author{
Shalini Bhorkar and Mark Bray
}

\begin{abstract}
This paper analyses relationships between private supplementary tutoring and mainstream schooling in urban Maharashtra, India. The role of private tutoring progressively expands from the lower to the higher grades, and is especially visible in Classes 11 and 12 when it seems to supplant rather than supplement mainstream schooling. The paper notes the complex interplay of social, economic and educational factors in the shifting relationships, and has relevance not only for other parts of India but also other countries. The dynamics of private tutoring should be considered when conceptualising educational processes and devising policies for schooling, especially in relation to social inequalities and the efficiency of school systems.
\end{abstract}

Keywords: India; Maharashtra; private supplementary tutoring; shadow education; social inequalities; unregulated markets

\section{INTRODUCTION}

Across the globe, private supplementary tutoring (PST) has become a major educational issue for policymakers, practitioners and researchers, and has received attention in this journal as well as elsewhere (e.g. Bray et al., 2016; Entrich, 2018; Jheng, 2015; Jokić, 2013; Pallegedara \& Mottaleb, 2018). Increasing numbers of children in public schools, and sometimes also their counterparts in private schools, receive additional instruction outside school hours on a feepaying basis. This instruction may be delivered on a one-to-one basis, in small groups, in large classes or over the internet. Some forms of tutoring are commonly called shadow education on the grounds that their curricula mimic the provision in schooling (Aurini et al., 2013; Bray, 1999; 2009). Other forms of tutoring expand on and complement the curriculum of schooling; and, as this article notes, some tutoring actually supplants schooling.

India is among countries with significant scale of PST. A 2014 survey by the government's National Sample Survey Office (NSSO, 2016, p.98) reported enrolment rates in commercial enterprises known as coaching centres of $37.8 \%$ among boys at the level of lower and higher secondary schooling, and 34.7\% among girls. Additional students, not recorded, 
would have been receiving individual and small-group PST from teachers, university students and other informal providers. A second survey, focusing on 12 cities though with a small and perhaps biased sample in each, reported that in 2013 "up to 95\% [of] students in high schools” were receiving private tutoring (ASSOCHAM, 2013). Whatever the actual number, tutoring dominates the lives of many families - including those who worry that their children are not receiving it - and is highly visible on billboards, websites, and the shop-fronts of tutorial centres.

Despite the widespread nature of the phenomenon in India, little research has been conducted there. The present study focuses on the experiences of higher secondary students in an urban region of Maharashtra State. It is a qualitative study that assesses the role of PST in relation to mainstream schooling. Some forms of tutoring have moved beyond supplementation to become substitutes that supplant regular schooling. This evolution has significant implications for educational structures and processes, and for malpractices resulting from an unorganised and unregulated tutoring sector. Informal evidence suggests that patterns in Maharashtra have parallels elsewhere in India, though to the authors' knowledge they have not been examined in the way that is done in this paper. Similar remarks apply to other countries, so the paper has international as well as national and local relevance.

\section{LITERATURE REVIEW}

In line with much existing literature (e.g. Bray, 1999; Kobakhidze, 2014; Pallegadara \& Mottaleb, 2018; Zhang, 2014), this paper focuses on educational provision beyond that provided by formal schools on a fee-paying basis. Studies in countries with extensive private tutoring have shown a backwash on mainstream schooling (Bray et al., 2016; Jokić, 2013). Despite the likely positive effects on students' academic performance, several major problems are commonly identified. One is about the burden on students caused by excessive focus on examinationoriented skills; and a second is about reduced momentum to improve public education because of diverted motivation for quality improvement. In the most problematic situations, students absent themselves from mainstream schools in order to devote their time and energy to PST. This has been noted anecdotally in countries as diverse as China, Egypt and Myanmar, and has been touched upon by researchers in Azerbaijan and Turkey (Silova \& Kazimzade, 2006, p.128; Tansel \& Bircan, 2008, p.19), but has not been investigated thoroughly. Such absenteeism has serious repercussions on mainstream schooling; and as private tutoring participation rates grow, absenteeism tends to rise further.

The context for much international literature is the rise of privatisation in the education sector, which has displaced the view that schooling should be exclusively a state-provided 
service (Macpherson et al., 2014; Verger et al., 2016; Ward, 2013). Much of the literature on privatisation in education has focused on schools, highlighting both market-oriented reforms within public schools and the proliferation of private institutions alongside public ones (e.g. Ball \& Youdell, 2008). The expansion of PST is a further mechanism through which balances of public and private have been altered (Aurini et al., 2013; Bray, 2017; Manzon \& Areepattamannil, 2014; Silova et al. 2006; Zhang \& Bray, 2017). As this paper shows, it is largely a bottom-up process rather than the result of deliberate policies. It results in what Cowen (2009) called "shape-shifting”. Cowen was more concerned within the field of comparative education with policies and practices that cross international borders, but the present article shows that shapes also shift over time within single jurisdictions.

Turning specifically to the literature on PST in India, the few available studies (e.g. Aslam \& Atherton, 2013; Azam, 2015; Majumdar, 2014, 2018; Salovaara, 2017) reflect views in the wider literature that PST can compensate for shortcomings in mainstream education but may also contribute to inefficiencies. The research also highlights the impact of PST on social disparities by creating unequal learning opportunities. Although overall enrolment rates in tutoring are high, many students have to enrol in cheaper forms that do not meet their needs effectively. Among ironies is that many students indicate that they seek tutoring because their schools have large classes and ineffective teaching, but then proceed to tutoring in classes of similar sizes taught by tutors with doubtful qualifications and credentials (Agarwal, 2015; Maheshwari, 2015).

Further issues arise from the fact that PST seemingly nullifies the efforts of well-intentioned government initiatives such as Right to Education (RTE) Act and Sarva Shiksha Abhiyan (SSA) ${ }^{1}$ that aim to provide equal and good quality educational opportunities to every child (Sen, 2009). The RTE Act required private schools to accept students from all social strata under a 25\% reservation quota scheme (MHRD, 2016), but students who climb the educational ladder from government schools to private schools may be driven to PST to keep up with their peers (Kulkarni, 2016; 2017). The West Bengal State government's removal of English from the elementary curriculum with the intention of making primary education accessible to rural and poor children caused many parents to enrol their children in private English lessons to bridge the gap; and once this pattern had become established, reversal of the government policy did not lead to withdrawal from PST (Roy, 2010). Curricular load is often cited as one of the drivers of

1 The Sarva Shiksha Abhiyan (SSA) programme, operational since 2000/01, aims at the universalisation of elementary education irrespective of gender and social category (MHRD, 2016). 
PST, both nationally and internationally (e.g. Jokić, 2013; Maheshwari, 2015; Sen, 2009). However a study in Bengaluru, Karnataka State, observed high enrolment rates irrespective of streams that had differing curricular loads (Ghosh \& Bray, 2018). PST also seems to contribute to dropout rates because some parents see no educational future for their children if they are unable to supplement their mainstream schooling with private tutoring (Chugh, 2011; Chhapial, 2013; Sen, 2009).

\section{RESEARCH OBJECTIVES}

This study in a society with high PST participation rates focused on relationships between private tutoring and mainstream schooling. It was based on the hypothesis that private tutoring has become so important in higher secondary students' lives that it plays a larger role than the mainstream. As illustrated in Figure 1, when the role of private tutoring exceeds that of the mainstream, it may not be just supplementary in nature and is likely to supplant mainstream education. The mode of private tutoring is also likely to change from informal tutoring services to more formal provision.

Figure 1: Hypothesised relative roles of mainstream schooling and private tutoring
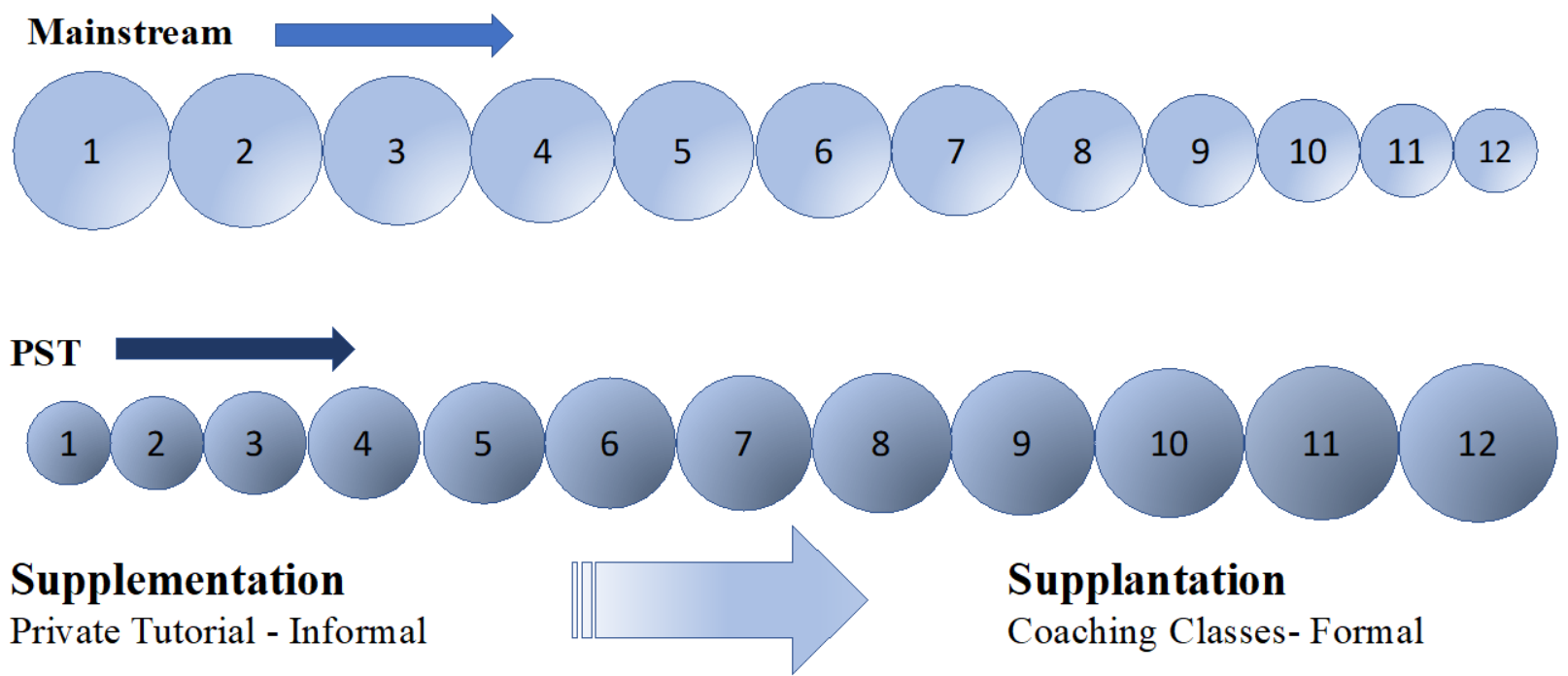

Note: Each circle represents the school year, e.g. 1 is Class 1, 2 is Class 2, etc.

The study investigated the roles of PST vis-à-vis mainstream education in the lives of higher secondary students in terms of 1) their choices of tutorial class, costs, and class size, 2) subjects, 3) time spent and curriculum covered, and 4) relationships with teachers in their mainstream institutions and tutors in the private tutoring. The research focused on science 
students since they are generally considered the elite in highly competitive circumstances. In 2017, 37.2\% of students sitting the Maharashtra State Board Class 12 examinations were in the science stream, $24.8 \%$ were in the commerce stream, $33.8 \%$ were in the arts stream, and $4.2 \%$ in vocational courses. The number of Science students was about 559,000 , of which $70 \%$ also sat engineering/pharmacy entrance tests and 45\% sat medical entrance tests (MSBSHSE, 2017). The study also sought to understand the expansion of private tutoring during their years of schooling since Class 1 . The aims led to the following questions:

1. What role has PST played in the lives of the students in their two years of higher secondary schooling (Classes 11 and 12) vis-à-vis their mainstream institutions?

2. How did the roles change over their years of schooling, from primary to lower secondary and then to higher secondary?

3. Has private tutoring supplanted mainstream institutions and, if so, why and with what implications?

\section{CONTEXT IN MAHARASHTRA STATE}

Maharashtra is India's second most-populous state (after Uttar Pradesh), and the third largest in area (after Rajasthan and Madhya Pradesh). It is also one of India's most educationally and economically developed states.

School education in Maharashtra is delivered through government schools which are wholly publicly funded and managed, private aided schools which are managed privately but partially funded by government, and private unaided schools which are wholly privately funded and managed. Classes 1-4 are called primary, Classes 5-7 upper primary, Classes 8-10 secondary, and Classes 11-12 higher secondary. The Maharashtra State Board of Secondary and Higher Secondary Education (MSBSHSE) conducts public examinations, commonly known as board examinations, at the end of Classes 10 and 12. Students can choose to study through English, Marathi (the state language), or Hindi. A few schools alternatively offer education in other Indian languages to serve populations from other states. In some schools, students have the option of switching to English for science and mathematics, usually in Class 8 after studying in any vernacular medium until Class 7.

In this paper, the term 'mainstream education' refers to schooling provided up to Class 12 in fully public or government-aided institutions. In many Indian states, students may proceed to Class 12 all the way in single institutions or at least during their secondary schooling. This is also possible in Maharashtra, though large numbers of higher secondary students undertake their 
Class 11 and 12 studies in junior colleges. This vocabulary causes some confusion since it seems to overlap with tertiary education; and indeed many junior colleges are attached to tertiary institutions that offer undergraduate courses such as Bachelor of Arts (BA), Bachelor of Commerce (BCom) or Bachelor of Science (BSc). Nevertheless, in both official parlance and common perception, the junior colleges are part of the mainstream school system rather than part of tertiary education.

The survey by Sujatha and Rani (2011, p.113) in Maharashtra’s Pune District indicated greater private tutoring participation in higher secondary (40.0\%) compared with districts in Kerala (33.5\%) and Uttar Pradesh (34.9\%). The survey also indicated large percentages of Pune students undertaking tutoring at commercial coaching centres. Coaching classes and informal home-tutoring by teachers and others proliferate with a laissez-faire approach from the government, and are also very evident in the city on which the present study focuses.

\section{METHODOLOGY}

Multiple qualitative research methods were employed to address the research objectives (Merriam, 2009; Rossman \& Rallis, 2017). The first research question required an exploratory approach, while the second question needed retrospective methods to assemble data from the students towards the end of their schooling. The last question required an interpretive angle to assimilate all the gathered data for identification of the extent of supplementation. Narrative methods were used to collect descriptive accounts in a systematic, chronological order of school years. Research instruments included questionnaires to gather demographic information and the students' PST histories, semi-structured interviews with students and PST providers to collect data pertaining to PST experiences, and unstructured interviews with parents for data triangulation and additional probing. Newspaper articles and websites of tutoring centres aided the understanding of the different modes of private tutoring, and textbooks for both the state and central syllabi were also analysed. Finally, the contents of question papers of public examinations and entrance tests for higher education courses were studied to confirm the validity of some of the participants' statements.

Literature on Japan, Korea and Hong Kong, where shadow education has been relatively well-researched, shows that the percentages of students undertaking private tutoring are highest in the last year of secondary schooling (KOSIS, 2015; MEXT, 2015; Zhan et al., 2013). Indian studies also indicate particularly high participation rates and intensities at this level, especially among science students (Azam, 2015; Sujatha, 2014). These factors, along with the longitudinal aspect of this study in comparing the roles of PST vis-à-vis mainstream education over the entire 
schooling career, required access to science students who had just completed Class 12. Methodologically, the study benefitted from the fact that students in this age group had the maturity to understand the dynamics and complexities of both the mainstream and parallel forms of education, and offered holistic perspectives on their experiences.

The participants were chosen from Ambernath, a city 50 kilometres from the state capital, Mumbai, which may be considered typical in Maharashtra. A combination of opportunistic and snowball sampling was used to select the interviewees. Before commencing fieldwork, ethical clearance was obtained from the university under the umbrella of which the research was conducted. Piloting of instruments was undertaken with two students in Pune which, as noted above, also has high percentages of PST. The original plan had included students not receiving tutoring, to provide maximum variation; but despite persistent efforts no such student could be identified. The final list of interviewees comprised:

- 12 Class 12 science students (six male and six female), aged 17-18,

- 10 parents of these students, and

- three tutors and one administrator from a coaching centre.

The interviews were conducted in English, Hindi, Marathi, Tamil or a combination of these languages according to the preferences of the interviewees. Data were transcribed in English and grouped into categories and themes.

Following Johnson and Christensen (2014, p.266), multiple interpretations from different people about similar aspects of PST from both supply and demand sides were utilised to increase the trustworthiness of the study. Overall, these interpretations converged with considerable consistency; and analysis of the textbooks and examination papers validated data on differences in curricula and the extent to which the examination questions demanded rote memorization rather than critical thinking. Several findings of this study matched newspaper reports, thereby increasing what Cohen et al. (2000, p.121) called the "convergent validity" of the data.

\section{FINDINGS AND DISCUSSION}

\subsection{Participants}

Among the 12 student participants, all had attended private aided schools until Class 10 and had then proceeded to junior colleges or higher secondary schools. The families would have paid some fees for their children in private aided schools, albeit at a heavily subsidised rate, and evidently felt a need to make further payments for supplementary tutoring. Between them, the students had attended five different (lower) secondary schools, two higher secondary schools that 
were extensions of (lower) secondary schools, and five different junior colleges. As such, some sub-groups had commonalities but the total group had diversity.

The reported family monthly incomes for nine families were in the range of Rs.30,000 (US\$468) to Rs.40,000 per month. ${ }^{2}$ For two families the reported family incomes were Rs.50,000 to Rs.60,000, and in one family the reported income was Rs.20,000. Official figures (DES, 2017) reported 2015/16 average monthly per capita incomes in the state at about Rs.12,300; but considering the extreme disparities and high cost of living in cities, for this group Rs.30,000-40,000 could still be considered middle class. Thus, most families were in the middle of the middle class, with two families in the upper middle and one in the lower middle. All the interviewed parents had at least high school education; most were university graduates, and four had postgraduate degrees or diplomas.

While all the students received tutoring at commercial coaching centres, five also received one-to-one or small-group tutoring at home or in their tutors' residences. None of the PST providers had any formal training in education, and their enterprises appeared chiefly to operate for economic rather than educational reasons.

\subsection{Role of PST in Higher Secondary}

The first research question required review of the students' educational journeys over their two years of higher secondary schooling. It aimed to understand their considerations about PST in relation to mainstream education when making choices about coaching classes, including the significance of costs and class sizes. It also considered the subjects for PST, the time spent and curriculum covered, and the students' relationships with tutors and mainstream teachers. Each of these topics is summarised below.

\subsubsection{Choice of coaching classes}

The MSBSHSE examination authorities declare Class 10 Secondary School Certificate (SSC) results in June each year. Most students then finalise their choices for Class 11 streams, knowing that junior colleges have cut-off marks for admissions in Science, Commerce or Arts, and that Science usually requires the highest percentage. However, coaching classes also play significant roles in choices of junior colleges. Eight of the 12 students had already enrolled in coaching classes for the subjects of their anticipated streams before the results were declared, and the selection of coaching centres had demanded much time and effort from both students and parents.

\footnotetext{
${ }^{2}$ All conversions from Indian rupees to US dollars are based on the rates on 1 August 2017, US\$1 = Rs.64.095.
} 
Three students had joined coaching classes soon after their Class 10 results were declared, and the remaining one had joined at the end of Class 11. Thus, for all 12 students the choice of mainstream college had been taken based either on the recommendation of the coaching centre or with consideration of the location of colleges close to the coaching centres.

Interrelationships in Classes 11 and 12 were further evident in the experiences of two students who had enrolled in "integrated courses" run by coaching centres. In these courses, the students learned much theory pertinent to their subjects. They were required to enrol in the junior colleges, which in any case were the ones recommended by their coaching centres, but did not have to attend the colleges regularly. The fees to the coaching centres were substantially higher than those to the junior colleges, in part because the centres made payments to the junior colleges to mark the students as having been present and to exempt them from attending lessons or conducting experiments. As reported in the press, this has not only been an expanding phenomenon elsewhere in Maharashtra, but also raises questions about corruption (Bhandary, 2016; Chaudhari, 2016; Times of India, 2016; Qazi, 2016a). The junior college fees were about $10 \%$ of the coaching centre costs, but class sizes were comparable. Classes in the junior colleges had 60 to 65 students, while those in the coaching centres were about the same or slightly more.

\subsubsection{Subjects}

The authorities have been concerned about over-specialisation of students and lack of all-round development. With this in mind, the examination board (MSBSHSE, 2012) has declared a requirement for diversity of subjects as shown in Table 1. However, the attention to the additional components was minimal. For English, all 12 students reported that their coaching classes (rather than their schools) provided grammar lessons two weeks prior to the board examinations. The students also received sheets containing questions and answers on their prose and poem chapters, for which all 12 students resorted to rote learning. For Environmental Education and for Health \& Physical Education theory, the mainstream institution had put on a notice board a question bank and model answers a few weeks before the board examinations. Ten students photographed these sheets with their mobile phones and memorised them. One student who had stopped attending junior college in Class 12 obtained these sheets from a friend in the coaching class; and the remaining student, who was enrolled in an integrated class, obtained similar question banks and answer sheets from her coaching class. Thus, the authorities' efforts to promote all-round development were subverted by the coaching classes with the tacit acceptance of the mainstream institutions. 
Table 1: Subjects prescribed by MSBSHSE

\begin{tabular}{|l|l|}
\hline Compulsory Subjects (All four) & Elective Subjects (Any four) \\
\hline English & Mathematics \& Statistics \\
\hline $2^{\text {nd }}$ Language or Information Technology & Physics \\
\hline Environmental Education & Chemistry \\
\hline Health \& Physical Education & Biology \\
\hline & Information Technology \\
\hline & $\begin{array}{l}\text { Any vocational subject (for Physics, Chemistry \& } \\
\text { Mathematics group - required for aspiring engineering } \\
\text { students) }\end{array}$ \\
\hline & $\begin{array}{c}\text { Any humanities subject (for Physics, Chemistry \& Biology } \\
\text { group -required for aspiring medicine students) }\end{array}$ \\
\hline
\end{tabular}

\subsubsection{Time spent and curriculum covered}

The students spent a maximum of six hours per week in their mainstream institutions compared with an average of 27 hours per week in coaching classes. The MSBSHSE (2012) recommends that for every four theory lessons, students should have three sessions in science laboratories to conduct experiments called 'practicals'. However, as the curriculum in coaching classes did not include practicals, the students received at least $50 \%$ more than the time allotted to them for theory lessons in mainstream institutions. As noted, junior colleges commonly received payments from the coaching centres to mark the students enrolled in integrated courses as having attended the practical classes when in fact the students had not done so. Table 2 illustrates the reported actual learning of the students.

Table 2: Students' reported actual learning, by category

\begin{tabular}{|l|l|c|}
\hline Category & Attendance & No. of students \\
\hline \multirow{2}{*}{$\begin{array}{l}\text { Theory lessons at } \\
\text { mainstream institution }\end{array}$} & Regularly in Class 11 & 1 \\
\cline { 2 - 3 } & First month only in Classes 11and 12 & 9 \\
\cline { 2 - 3 } $\begin{array}{l}\text { Practicals at mainstream } \\
\text { institution }\end{array}$ & Never & 10 \\
\cline { 2 - 3 } & Once every week & 1 \\
\cline { 2 - 3 } $\begin{array}{l}\text { Theory lessons at } \\
\text { coaching centre }\end{array}$ & $\begin{array}{l}\text { Onysics, Chemery semester, and twice before final examinations } \\
\text { for about 4.5 hours per day for about 300 days each in } \\
\text { Classes 11 and 12 }\end{array}$ & 12 \\
\hline $\begin{array}{l}\text { Other compulsory and } \\
\text { elective subjects }\end{array}$ & $\begin{array}{l}\text { English, Environmental Education, and Health \& Physical } \\
\text { Education: two weeks prior to final examination }\end{array}$ & 12 \\
\hline $\begin{array}{l}\text { Examinations at } \\
\text { mainstream institution }\end{array}$ & $\begin{array}{l}\text { End of Class 11: once } \\
\text { Preliminary (Mock) Examinations in Class 12: once } \\
\text { Final board examination }\end{array}$ & 12 \\
\hline $\begin{array}{l}\text { Examinations practice at } \\
\text { PST centre }\end{array}$ & $\begin{array}{l}\text { Multiple tests and five to six preliminary (mock) } \\
\text { examinations }\end{array}$ & 12 \\
\hline
\end{tabular}




\subsubsection{Relationship with teachers}

Ten students reported that their relationships with mainstream teachers had been limited to a few interactions during practical sessions, and the other two students reported even fewer communications. The students had spent most of their time with the coaching class teachers or private tutors. The students stated that the instructors in the tutoring sector were far more knowledgeable, inspiring and helpful than the teachers in the mainstream institutions, and relied on them for all their educational needs including preparation for examinations.

\subsection{Patterns of PST until Class 10}

The second research question concerned the students' outside-school learning in the years until Class 10. It sought information on when and why the students embarked on PST, and how the interplay between the PST and mainstream schooling had developed over the years.

Table 3 presents the findings. All interviewees highlighted the necessity for household academic support, especially during the early stages. During the primary and lower secondary years, the major reported factors for seeking PST were large classes in school since teacherstudent ratios were about 1:70, and English or another medium of instruction that did not match the home language. Families felt better able to support their children when the curriculum content was elementary, and felt decreasingly competent when the students moved into secondary schooling. The lower the educational qualification of the parents and less their availability at home, the sooner the families resorted to PST.

\section{Table 3 : Tutoring experiences of the students until Class 10}

\begin{tabular}{|c|l|l|l|}
\hline Student & $\begin{array}{l}\text { Prior to start of } \\
\text { PST }\end{array}$ & Mode when first joined PST & Reasons for availing PST \\
\hline 1 & $\begin{array}{l}\text { Mother helped daily } \\
\text { until Class 2 }\end{array}$ & $\begin{array}{l}\text { Class 3: small group PST; } \\
\text { Class 9 summer: medium-size } \\
\text { group PST }\end{array}$ & $\begin{array}{l}\text { Parents are high school graduates; } \\
\text { Lack of Hindi and Marathi skills; } \\
\text { Difficulty in homework; } \\
\text { Parents wanted habit of regular studies }\end{array}$ \\
\hline 2 & $\begin{array}{l}\text { Self-study until } \\
\text { Class 8; parents and } \\
\text { sister helped }\end{array}$ & $\begin{array}{l}\text { Class 9 summer: coaching classes } \\
\text { until Class 6 }\end{array}$ & $\begin{array}{l}\text { Preparation for board examinations; } \\
\text { Get used to routine of coaching classes }\end{array}$ \\
\hline 3 & $\begin{array}{l}\text { Mother helped daily } \\
\text { until Class 8 }\end{array}$ & $\begin{array}{l}\text { Class 9: coaching classes } \\
\text { Class 9 summer: coaching classes }\end{array}$ & $\begin{array}{l}\text { Did not wish to study with parents; } \\
\text { Students proved ineffective; changed to } \\
\text { coaching classes }\end{array}$ \\
\hline 5 & $\begin{array}{l}\text { Parents helped daily } \\
\text { until Class 7 }\end{array}$ & $\begin{array}{l}\text { Class 8: coaching classes } \\
\text { meeded organised, better-planned study } \\
\text { methods for Class 10 board examinations }\end{array}$ \\
\hline 6 & $\begin{array}{l}\text { Parents and brother } \\
\text { helped when needed }\end{array}$ & Class 9 summer: coaching classes & $\begin{array}{l}\text { Get used to routine of coaching classes; } \\
\text { Everybody else was doing it }\end{array}$ \\
\hline
\end{tabular}




\begin{tabular}{|c|l|l|l|}
\hline 7 & $\begin{array}{l}\text { Parents and brother } \\
\text { helped when needed }\end{array}$ & $\begin{array}{l}\text { Class 8: small group PST } \\
\text { Class 9 summer: coaching classes }\end{array}$ & $\begin{array}{l}\text { Needed help in mathematics; } \\
\text { Friends joined coaching classes }\end{array}$ \\
\hline 8 & $\begin{array}{l}\text { Self-study; parents } \\
\text { helped }\end{array}$ & Class 9: coaching classes & $\begin{array}{l}\text { Wanted to score well in board } \\
\text { examinations }\end{array}$ \\
\hline 9 & $\begin{array}{l}\text { Self-study; father } \\
\text { and school teachers } \\
\text { helped }\end{array}$ & No PST until Class 11 & $\begin{array}{l}\text { Did not undertake PST as student } \\
\text { consistently stood first in class, was } \\
\text { diligent and self-motivated }\end{array}$ \\
\hline 10 & $\begin{array}{l}\text { Mother helped daily } \\
\text { until Class 8 }\end{array}$ & Class 9 summer: coaching classes & $\begin{array}{l}\text { Get used to routine of coaching classes; } \\
\text { School teachers were not adequate }\end{array}$ \\
\hline 11 & $\begin{array}{l}\text { Self-study until } \\
\text { Class 6 }\end{array}$ & $\begin{array}{l}\text { Class 7: small group PST } \\
\text { Class 9 summer: coaching classes }\end{array}$ & $\begin{array}{l}\text { Poor results in Class 6; Coaching class } \\
\text { better for board examinations }\end{array}$ \\
\hline 12 & $\begin{array}{l}\text { Parents and brother } \\
\text { helped when needed }\end{array}$ & $\begin{array}{l}\text { Class 7: Small group PST } \\
\text { Class 9 summer: coaching classes }\end{array}$ & $\begin{array}{l}\text { Found mathematics difficult; Coaching } \\
\text { classes helped utilise summer vacation } \\
\text { after Class 9 }\end{array}$ \\
\hline
\end{tabular}

The fact that 11 out of 12 students relied on coaching classes for their Class 10 board examinations reflected a belief that coaching classes significantly assisted in the preparation for those examinations. Maharashtra has become known for the so-called Latur Coaching Pattern (Sujatha \& Rani, 2011, p.152), which was started in Latur District and then emulated. In this model, Class 10 and Class 12 syllabuses are commenced in Classes 9 and 11 as a form of 'preteaching'. The schools commonly view this model with ambivalence. It alleviates their instructional burden and may improve results for which the schools as well as the coaching centres take credit, but it exacerbates diversity within the classroom and leads many students who have received pre-teaching to feel bored when they hear the content a second time.

\subsection{From Supplementation to Supplantation}

The third research question asked whether PST supplanted mainstream institutions and, if so, sought to identify the causes and implications. The above remarks about pre-teaching are part of the answer. This section elaborates, drawing not only on the interview data but also on other sources. It notes different patterns at different stages of students' school careers.

\section{$\underline{6.4 .1 \text { Until Class } 9}$}

The years in which the students did not receive PST were characterised by household academic support, students' ability to manage studies, little worry about marks, and few peer pressures. The students turned to PST when they could not get enough help from family members and/or scored poorly in school examinations. Until Class 8, the support was largely supplementary, and included help with homework, improved understanding of subjects, remedial assistance, compensation for poor teaching in school, establishing routines for study, and improved performance in school tests and examinations. All 12 students attended their schools regularly 
during their 10 years of primary and secondary education. Time for PST was additional to that for schooling. It ranged from two to four hours, five to six times a week during school term, and did not occupy the summer vacation. The students were enrolled in tutoring for all subjects, with stress on mathematics which was taught on a daily basis and on science and languages a few times each week. Tutoring in other subjects was received only a few times each month. The whole prescribed syllabus was taught at school, and only the topics that students found difficult were addressed in their tutoring classes. All these facts pointed to the supplementary nature of PST.

\subsubsection{Class 9 to Class 10 board examinations}

Ten of the 12 students had enrolled in coaching classes at the end of Class 9, having chosen those classes rather than individual tutoring. Features were as follows:

- $\quad$ students begin to receive pre-teaching of all Class 10 subjects in the summer after Class 9, giving them head start for board examinations and covering $10-40 \%$ of the syllabus;

- lessons on weekends, public holidays and school holidays to secure regularity without space for students to fall out of routine;

- $\quad$ students streamed into different groups based on their test scores;

- $\quad$ regular tests in each subject to help students identify their strengths and weaknesses;

- multiple mock examinations after completing the curriculum by December, to provide sufficient practice before the March board examinations.

During this stage the students still attended school regularly, and all interviewees indicated that their teachers strove to complete the syllabus within the school year. Thus the mainstream institution still delivered the curriculum, even though for many students it was repeat learning. Coaching classes were seen as supplementary, but a shift towards the independent role of PST began to appear because the coaching classes were deemed an absolute necessity for the board examinations. All 10 students attributed their high scores in Class 10 to the pre-teaching and constant examination drilling in their coaching classes. Students considered Class 10 marks as being important for their future streams, but they also considered the marks as vital in their choices of coaching classes for higher secondary. This was where a shift in the importance to PST over schooling could be observed, marking the divergence from mainstream institutions. 


\subsubsection{Classes 11 and 12 (Higher Secondary Education)}

During Classes 11 and 12, erosion of the mainstream role and strengthening of the PST role continued. The students and parents focused on the standing and reputation of the coaching classes, and did not give much thought to the mainstream institutions. For the two students who had undertaken integrated courses, mainstream education had been reduced to redundancy. In West Bengal State, Majumdar (2014) noted the risk of reduction of the mainstream role to mere issue of certificates; and the present study showed reduction of the syllabi and curricula that had been designed by the MSBSHSE. The inability of the researchers to find science students who were not receiving PST further reflected the extensiveness of tutoring. The existence and modes of operation of integrated courses run by coaching centres showed further blurring of boundaries. Indeed, some companies had started to call their coaching centres junior colleges.

\subsubsection{Supplementation to Supplantation}

Figure 2 summarises the role of PST in the lives of these students vis-à-vis their mainstream institutions. Figure 1 hypothesised the larger-than-mainstream role of PST in the all-important two years of higher secondary schooling. It also hypothesised a gradual reduction in the mainstream role taking place simultaneously with a gradual increase in the PST role. The interviews indeed showed that overall picture, though with variations from student to student. Figure 2 shows that the magnitude and importance of PST until Class 9 varied among the students according to the perceived quality of school teaching and the families' ability to provide academic support at home. The roles were reversed in Classes 11 and 12, as the magnitude and importance of mainstream education were linked to the kind of PST received by the students. The exception was in Class 10, when PST seemed to play an important role without reducing the students' mainstream participation.

A contributing factor in the shift may have been the physical transition for many students from their (lower) secondary schools to institutions called junior colleges that had different traditions and modes of operation. As noted above, however, the junior colleges were both officially and in common perception part of the mainstream school system rather than tertiary education. Moreover, the patterns of the student who stayed in her existing school up to Class 12 and of her peer who moved after Class 10 to a similar institution were not significantly different from the students who entered junior colleges. This might be a matter to explore further with a larger sample. 
Figure 2: Supplementation to Supplantation

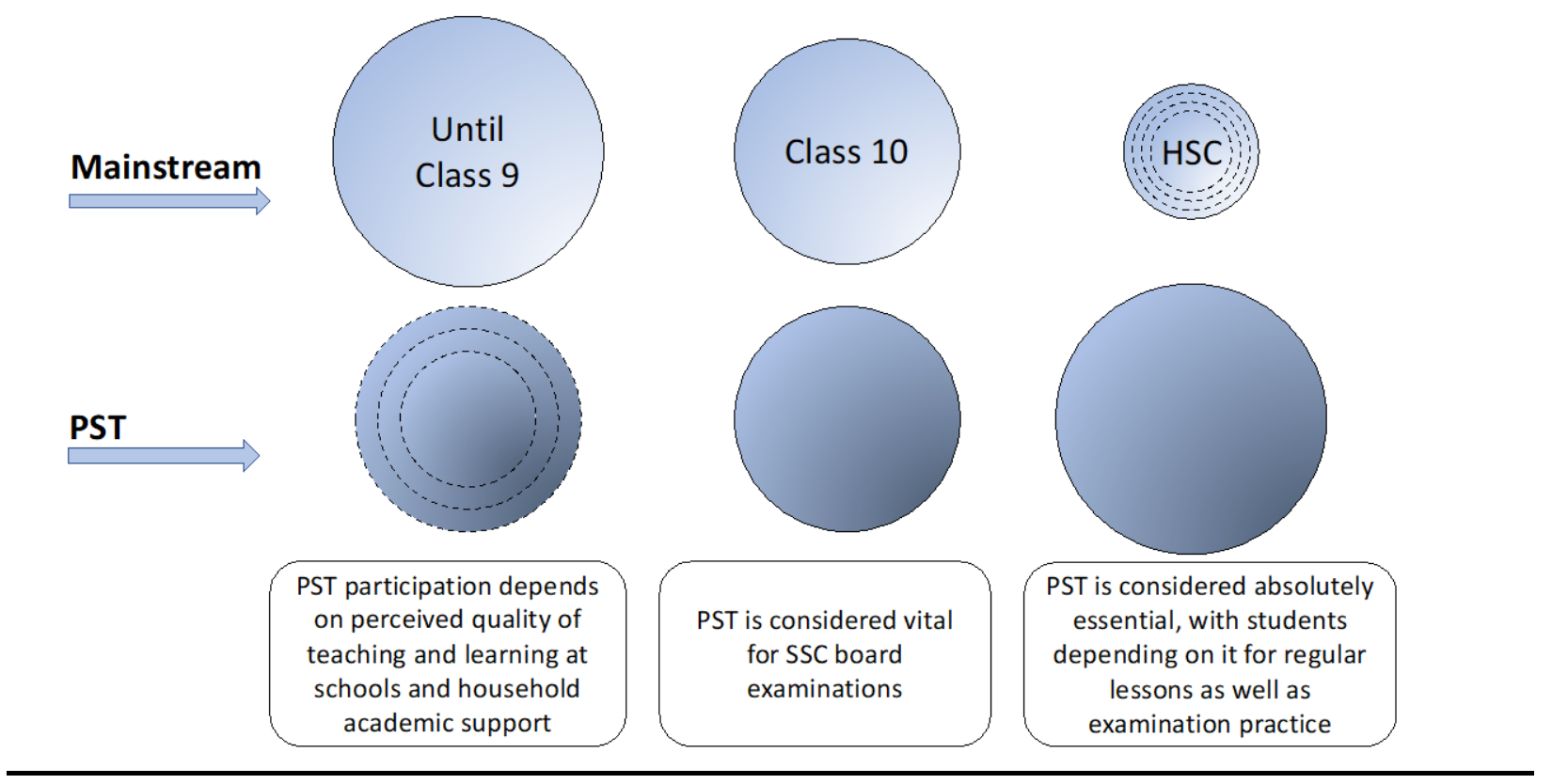

\subsubsection{Supplementation for PST}

Another point indicating the larger-than-mainstream role of PST was that PST seemed to have its own shadow. Over the years, many coaching classes had expanded their class sizes. Other research has cited large classes in the mainstream as one of the major determinants for PST in the first place (Sujatha \& Rani, 2011, p.138). When PST also started to have large class sizes, the pattern seemed to drive students to seek supplementation for their PST. This supplementation for supplementation was observed in the accounts of four students. As coaching classes are large to reduce unit costs and secure higher total revenues, students sought smaller PST groups or one-toone sessions for subjects or topics in which they had difficulty.

\subsubsection{Role of PST in preparing for entrance tests}

The system of entrance tests for higher education was a major reason for PST being perceived as more advantageous than the mainstream in the last two years of schooling. In the past, board examinations had been highly instrumental for selection to professional undergraduate courses such as engineering, pharmacy and medicine, but contemporary admissions were based on separate entrance tests for these specialisations. Coaching classes seem to provide an edge over mainstream institutions by facilitating simultaneous preparation for board examinations and entrance tests. Further, students faced much confusion each year regarding entry requirements and admission processes. The interviewees in this study, corroborated by newspaper articles, indicated that students and parents had little time to cope with sudden changes in the criteria for 
selection and in the curricula of the entrance tests (Hindustan Times, 2015; The Hindu, 2016; Times of India, 2017). Faced by the stress of keeping track of the changes, students and parents found the solution in the form of coaching class personnel, on whom they relied for the latest information. Parents seemed to find justification for the high coaching class fees in these services, for which they believed the mainstream had neither the responsibility nor the resources. Thus, the current system of entrance tests coupled with ongoing changes seem to facilitate the rapid growth of PST.

\section{CONCLUSIONS}

The multifaceted, complex nature of PST and the constantly evolving dynamics of its determinants require adjustments to conceptualisation of shadow education in the literature (e.g. Bray, 1999, p.20; Kenayathulla, 2013, p.629; Sohn et al., 2010, p.25). On this definition, PST came into existence because of mainstream education, and changed in line with changes in the mainstream. The present study adhered to this definition insofar as students began to receive PST to assist their progress in mainstream institutions. At that time, their private tutoring was supplementary, paralleled mainstream education, and mimicked mainstream curricula. However, a divergence from the definition was evident when PST began to overshadow mainstream education in the last two years of schooling. Decisions regarding PST began to take precedence, and students spent more time in coaching classes than in their mainstream institutions. Also, curricular content and subjects available in PST but not mainstream institutions, particularly concerning the entrance examinations to tertiary institutions, gained more focus. Further, PST had its own shadow, as evidenced in the receipt of supplementation for PST, which thus demonstrated elements of PST's independent standing in educational processes. All these factors pointed to the larger-than-mainstream role in which PST was supplanting mainstream institutions.

A phenomenon of such magnitude is of course underpinned by multiple factors. At the widest level is the global environment. India's education sector has been characterised by an increased blurring of boundaries between state and market, thereby resulting in new models for distribution of educational services (Kumar, 2016). Moreover, the role of education in preparing a skilled workforce for the global economy has led to rapid growth in the number of private schools and higher education institutions, and intensified competition among students (Sadgopal, 2009). PST companies provide an edge for families in the competitive environment (Majumdar, 2018; Ørberg, 2018).

Related to these forces are various social and economic factors, including credentialism (Ghosh \& Bray, 2018). The total price that the parents in this study paid for their children's PST 
for Classes 11 and 12 ranged from two months to eight months of their household incomes. The parents saw this as a crucial expenditure for a short period of their children's lives, and had been saving money in order to be able to afford it. Five of the 12 students were single children, and the other seven had only one sibling. Middle-class families thus had smaller families. These patterns had parallels in other countries where steady economic growth has increased per capita incomes and middle-class families have had fewer children (see e.g. Aurini et al., 2013; Jokić, 2013; Zhang \& Bray, 2017). The combination first of greater wealth available to educate smaller numbers of children, and second of perceptions of the positive correlation between the fees for the coaching centres and the anticipated gains, has greatly increased demand; and the free market economy with little government regulation ${ }^{3}$ has permitted proliferation of PST companies operated by alert entrepreneurs.

In this context, educational factors are also important. Despite improvements the quality of mainstream education remains problematic (MHRD, 2016; NAS, 2015), and for families PST seems to be a remedy. Further, the strong emphasis on marks at each transition point in the education system fuels the PST participation rate. As elsewhere (see e.g. Bray, 2009; Bray \& Lykins, 2012), stress in the mainstream leads to PST enrolments even though PST then becomes a further source of stress with its own academic and time demands. The students and families interviewed in the present study seemed to handle the double stress of attending mainstream institutions and PST up to Class 10, but thereafter they downplayed the mainstream in favour of the PST. The mainstream institutions nevertheless continued operation, despite having been made even more inefficient by the backwash of PST. Parallels exist with patterns in Egypt reported by Hartmann (2008, p.81), where regular schooling has been similarly "reduced to a more or less redundant obligation”. The Indian authorities require students to be registered in schools in order to sit the official examinations; and the examination bodies require students to have conducted some practical work which needs laboratories that exist in schools but are not generally available in the coaching centres. Were these requirements to be relaxed, many students would abandon the regular schools altogether in favour of the coaching classes.

The study shows many other legitimacy ambiguities, including the so-called integrated courses and coaching centres that called themselves junior colleges. The issue of coaching

\footnotetext{
${ }^{3}$ The 1948 Bombay Shops and Establishments Act has been the major law under which the coaching centres have been operating in Maharashtra. The 2000 Maharashtra Coaching Classes (Regulation) Ordinance laid more specific rules regarding registration procedures. However, these laws merely specify registration requirements and procedures, and they have not been strictly implemented (Bhandary, 2016; Kulkarni, 2016).
} 
classes operating in college premises has received some legal attention (Chhapial, 2016; Qazi, 2016b); but the integrated courses noted in this study operated in the premises of the coaching centres which had established tie-ups with junior colleges. Such interrelationships increase the challenges of devising and implementing regulations. These forms of shape-shifting (Cowen, 2009) arise because of free market forces within an environment in which the state still sets the rules of the game in the form of examinations and certification.

The question then arises whether the government should be concerned about the problem. Again citing the Egyptian case, Hartmann observed (2008, p.81) that "it may in fact be easier and more cost-effective for the state to tolerate the 'corrupt practice' of private tutoring than to try and eliminate it”. Certainly it would be possible for the ambiguities to be sustained; but the contradictions seem to be intensifying and at some point may reach a breaking point. Among the main reasons why the state should maintain its own institutions is to permit equity in access for low-income families that lack the financial and social capital to secure education for their children in the marketplace. Such equity of access is only meaningful if the mainstream institutions are sufficiently robust, which in turn stresses the importance of improving the quality of the mainstream so that the PST is not an essential supplement let alone substitute.

Yet this study has also shown that the educational reasons for seeking PST are not limited to the quality of mainstream education. Another factor arises from the ambiguities in higher education entry requirements, and stresses the need for the government to address more fully the gaps between what is taught in the mainstream and what is required by the higher education selection systems. The advertisements of coaching centres are not limited to listing the names and scores of successful students, but include aggressive marketing of their additional role in higher education counselling which seemed to be completely missing from the mainstream institutions. Tackling of issues resulting from the endemic PST sector, driven by a motley of supply and demand factors, may require multipronged approaches.

This study has limitations arising from the fact that it is small in scale and limited to a specific set of families in a specific location. It has also focused on students in the science stream rather than commerce or arts, recognising that the science stream is especially competitive. Further, although the patterns in Maharashtra display similarities with at least some other parts of the country (see e.g. Majumdar, 2014; Sujatha \& Rani, 2011), they may also be distinctive to that particular location. As such, the themes deserve follow-up with similar studies, both qualitative and quantitative, elsewhere in the country. Further, insofar as the themes resonate with patterns in such countries as China, Egypt, Myanmar and Turkey, much potential exists for instructive cross-national comparison. PST has much expanded across the world during the last two decades 
and will certainly not disappear (Bray, 2017). As such, the paper contributes to an important global as well as local agenda for research and policymaking.

\section{References}

Agarwal, P. (2015). Private tutoring in India. International Higher Education, (45), 21-23. https://ejournals.bc.edu/ojs/index.php/ihe/article/download/7919/7070, accessed 20 February 2018.

Aslam, M., \& Atherton, P. (2013). The shadow education sector in India and Pakistan: The determinants, benefits and equity effects of private tutoring. In I. Macpherson, S. Robertson and G. Walford (Eds.) Education Privatisation and Social Justice: Case studies from Africa, South Asia and South-East Asia. (pp.137-156). Oxford: Symposium Books.

ASSOCHAM [Associated Chambers of Commerce \& Industry of India] (2013). Private coaching poaches mainstream education. http://assocham.org/newsdetail.php?id=4050, accessed 20 February 2018.

Aurini, J., Davies, S. \& Dierkes, J. (Eds.). (2013). Out of the shadows: The global intensification of supplementary education. Bingley: Emerald.

Azam, M. (2015). Private tutoring: Evidence from India. Discussion Paper Number 8770. New Delhi: Institute for the Study of Labour.

Ball, S.J., \& Youdell, D. (2008). Hidden privatisation in public education. Brussels: Education International.

Bhandary, S. (2016, 18 April). Coaching class act: They make their rules. Hindustan Times. http://www.hindustantimes.com/mumbai/coaching-class-act-they-make-their-rules/storywvVL7cPGgFMuYQntbQlKcJ.html, accessed 20 February 2018.

Bray, M. (1999). The shadow education system: Private tutoring and its implications for planners. Paris: UNESCO International Institute for Educational Planning (IIEP).

Bray, M. (2009). Confronting the shadow education system: What government policies for what private tutoring? Paris: UNESCO International Institute for Educational Planning (IIEP).

Bray, M. (2017). Schooling and its supplements: Changing global patterns and implications for comparative education. Comparative Education Review, 61(3), 469-491.

Bray, M., Kobakhidze, M.N., Liu, J., \& Zhang, W. (2016). The internal dynamics of privatised public education: Fee-charging supplementary tutoring provided by teachers in Cambodia'. International Journal of Educational Development, 49, 291-299.

Bray, M., \& Lykins, C. (2012). Shadow education: Private supplementary tutoring and its implications for policy makers in Asia. Mandaluyong City: Asian Development Bank and Hong Kong: Comparative Education Research Centre, The University of Hong Kong.

Chaudhari, K. (2016, 10 December). HC asks Maharashtra govt to probe colleges that outsource classes to pvt firms. Hindustan Times. http://www.hindustantimes.com/mumbai-news/hc-asks-maharashtragovt-to-probe-colleges-that-outsource-classes-to-pvt-firms/storypYk2jhYWmeb3EMTZCfdudI.html, accessed 20 February 2018.

Chhapial, H. (2013, March 16). Line is blurring between schools, coaching classes. Times of India. http://timesofindia.indiatimes.com/city/mumbai/Line-is-blurring-between-schools-coachingclasses/articleshow/18997715.cms, accessed 20 February 2018.

Chhapial, H. (2016, March 17). Coaching classes in court against integrated courses. Times of India. http://timesofindia.indiatimes.com/city/mumbai/Coaching-classes-in-court-against-integratedcourses/articleshow/51448206.cms, accessed 1 January 2018. 
Chugh, S. (2011). Dropout in secondary education: A study of children living in slums of Delhi. New Delhi: National University of Educational Planning and Administration.

Cohen, L., Morrison, K., \& Manion, L. (2000). Research methods in education. Oxford: Routledge.

Cowen, R. (2009). The transfer, translation and transformation of educational processes: And their shapeshifting?. Comparative Education, 45(3), 315-327.

DES [Directorate of Economics \& Statistics] (2017). Economic Survey of Maharashtra 2016-17. Mumbai: Planning Department, Government of Maharashtra. https://mahades.maharashtra.gov.in/files/publication/ESM_Eng2016_17.pdf, accessed 5 January 2018.

Entrich, S.R. (2018). Shadow education and social inequalities in Japan: Evolving patterns and conceptual implications. Dordrecht: Springer.

Ghosh, P., \& Bray, M. (2018). Credentialism and demand for private supplementary tutoring: A comparative study of students following two examination boards in India. International Journal of Comparative Education and Development, 20(1), 33-50.

Hartmann, S. (2008). The informal market of education in Egypt: Private tutoring and its implications. Mainz: Johannes Gutenberg-Universität.

Hindustan Times (2015, 18 March). A bitter pill: Change in syllabus for MH-CET. Hindustan Times. http://www.hindustantimes.com/mumbai/a-bitter-pill-change-in-syllabus-for-mh-cet/storyIrj3kUUScRbZZv20hfOxvK.html, accessed 1 January 2018.

Jheng, Y.J. (2015). The influence of private tutoring on middle-class students' use of in-class time in formal schools in Taiwan. International Journal of Educational Development, 40, 1-8.

Johnson, B., \& Christensen, L.B. (2014). Educational research: Quantitative, qualitative, and mixed approaches. Thousand Oaks: SAGE.

Jokić, B. (Ed.) (2013). Emerging from the shadow: A comparative qualitative exploration of private tutoring in Eurasia. Zagreb: Network of Education Policy Centers.

Kenayathulla, H.B. (2013). Household expenditures on private tutoring: Emerging evidence from Malaysia. Asia Pacific Education Review, 14(4), 629-644.

Kobakhidze, M.N. (2014). Corruption risks of private tutoring: Case of Georgia. Asia Pacific Journal of Education, 34(4), 455-475.

KOSIS [Korean Statistical Information Service] (2015). Private education participation rate by school level.

http://kosis.kr/eng/statisticsList/statisticsList 01List.jsp?vwcd=MT ETITLE\&parentId=C\#SubCo nt, accessed 1 January 2018.

Kulkarni, T. (2016, November 23). The widening class divide. The Hindu. http://www.thehindu.com/opinion/columns/The-widening-class-divide/article16681132.ece, accessed 1 January 2018.

Kulkarni, T. (2017, April 11). Bengaluru school asks UKG student to take a transfer certificate for 'poor performance'. The Hindu. http://www.thehindu.com/news/cities/bangalore/ukg-student-asked-totake-a-transfer-certificate-for-poor-performance/article17929998.ece?homepage=true, accessed 1 January 2018.

Kumar, R. (Ed.). (2016). Neoliberalism, critical pedagogy and education. New York: Routledge.

Macpherson, I., Robertson, S. \& Walford, G. (Eds.) (2014). Education, privatization and social justice: Case studies from Africa, South Asia and South East Asia. Oxford: Symposium Books.

Maheshwari, S. (2015). Constraints and possibilities in small-scale research: A mixed-methods study in West Bengal, India. In M. Bray, O. Kwo \& B. Jokić (Eds.), Researching private supplementary tutoring: Methodological lessons from diverse cultures (pp.179-200). Hong Kong: Comparative 
Education Research Centre, The University of Hong Kong, and Dordrecht: Springer.

Manzon, M., \& Areepattamannil, S. (2014). Shadow educations: Mapping the global discourse. Asia Pacific Journal of Education, 34(4), 389-402.

Majumdar, M. (2014). The shadow school system and new class divisions in India. Working Paper Series, TRG Poverty \& Education. London: Max Weber Stiftung.

Majumdar, M. (2018). Access, success, and excess: Debating shadow education in India. In K. Kumar (Ed.), Routledge handbook on education in India: Debates, practices and policies (pp.273-284). New York: Routledge.

Merriam, S.B. (2009). Qualitative research: A guide to design and implementation. San Francisco: Jossey-Bass.

MEXT [Ministry of Education, Culture, Sports, Science \& Technology, Japan]. (2015). Survey on Expenditure on Children's Learning.

http://www.mext.go.jp/b_menu/toukei/chousa03/gakushuuhi/1268091.htm (in Japanese), accessed 1 January 2018.

MHRD [Ministry of Human Resource Development, Government of India]. (2016). National policy on Education 2016: Report of the Committee for Evolution of the New Education Policy. http://www.nuepa.org/New/download/NEP2016/ReportNEP.pdf, accessed 1 January 2018.

MSBSHSE [Maharashtra State Board of Secondary \& Higher Secondary Education]. (2012). https://mahahsscboard.maharashtra.gov.in/hsc_syllabus_pdf/hscsyllabus.pdf, accessed 1 January 2018.

MSBSHSE [Maharashtra State Board of Secondary \& Higher Secondary Education]. (2017). https://mahahsscboard.maharashtra.gov.in/stat/hsc17/HS-STRM.HTM, accessed 3 January 2018.

NAS [National Achievement Survey]. (2015). What students know and can do - Class X, 2015: A summary of national achievement survey. New Delhi: National Council of Educational Research and Training. http://www.ncert.nic.in/departments/nie/esd/pdf/NASSummary.pdf, accessed 1 January 2018.

NSSO [National Sample Survey Office] (2016). Education in India (NSS 71 ${ }^{\text {st }}$ round, January-June 2014, No.575 [75/25.2/1]. New Delhi: Government of India, Ministry of Statistics and Programme Implementation.

http://admin.indiaenvironmentportal.org.in/files/file/education\%20in\%20india\%20\%20nss_report.pdf, accessed 1 January 2018.

Ørberg, J.W. (2018). Uncomfortable encounters between elite and "shadow education" in India: Indian Institutes of Technology and the Joint Entrance Examination coaching industry. Higher Education, DOI 10.1007/s10734-017-020-5.

Pallegedara, A., \& Mottaleb, K. A. (2018). Patterns and determinants of private tutoring: The case of Bangladesh households. International Journal of Educational Development, 59, 43-50.

Qazi, M. (2016a, 17 April). Mumbai colleges or coaching institutes - Lines getting blurred. Hindustan Times. http://www.hindustantimes.com/mumbai/mumbai-colleges-or-coaching-institute-linesgetting-blurred/story-1XeHZNzTzqMUnv0BgsmHTI.html, accessed 1 January 2018.

Qazi, M. (2016b, 19 December). Maha govt to Bombay HC: Just 1 college has tie-up with coaching class. Hindustan Times. http://www.hindustantimes.com/mumbai-news/maha-govt-to-bombay-hc-just-1college-has-tie-up-with-coaching-class/story-dbJNuaBSy4lxy3y3jCXuzI.html, accessed 1 January 2018.

Rossman, G.B. \& Rallis, S.F. (2017). An introduction to qualitative research: Learning in the field. Fourth edition. Los Angeles: SAGE.

Roy, J. (2010). Can changing academic standards affect educational outcomes? Evidence from a policy experiment in India. Washington DC: Georgetown University. 
http://ncspe.tc.columbia.edu/working-papers/OP162.pdf, accessed 1 January 2018.

Sadgopal, A. (2009). Common school system and the future of India. In Y. Mishra, G.R. Panda \& C. Gonsalves (Eds.), Human rights and budgets in India (pp.70-86). New Delhi: Human Rights Law Network \& Centre for Budget and Governance Accountability.

Salovaara, I.M. (2017). The work of tuitions: Moral infrastructure in a Delhi neighborhood. Asian Anthropology, 16(4), 243-260.

Sen, A. (2009). Introduction - Primary Schooling in West Bengal. The Pratichi education report, 2, 9-18. http://pratichi.org/sites/default/files/Pratichi_Education-Report_II.pdf, accessed 1 January 2018.

Silova, I., Būdienè, V., \& Bray. M. (Eds.). (2006). Education in a hidden marketplace: Monitoring of private tutoring. Budapest: Open Society Institute.

Silova, I., \& Kazimzade, E. (2006). Private tutoring in Azerbaijan. In I. Silova, V. Būdienè, \& M. Bray (Eds.), Education in a hidden marketplace: Monitoring of private tutoring (pp.113-142). Budapest: Open Society Institute.

Sohn, H., Lee, D., Jang, S., \& Kim, T.K. (2010). Longitudinal relationship among private tutoring, student-parent conversation, and student achievement. KEDI Journal of Educational Policy, 7(1), 23-41.

Sujatha, K. (2014). Private tuition in India: Trends and issues. Revue International d'Éducation de Sèvres [Online] Symposium: Education in Asia in 2014. http://ries.revues.org/3796, accessed 5 January 2018.

Sujatha, K., \& Rani, G. (2011). Management of Secondary Education in India. New Delhi: Shipra and National University of Educational Planning and Administration (NUEPA).

Tansel, A., \& Bircan, F. (2008). Private supplementary tutoring in Turkey: Recent evidence on its various aspects. Bonn: Institute for the Study of Labor.

The Hindu (2016, 4 May). Worried students, anxious parents await SC verdict on medical entrance test. The Hindu. http://www.thehindu.com/news/cities/mumbai/news/worried-students-anxious-parentsawait-sc-verdict-on-medical-entrance-test/article8554091.ece, accessed 1 January 2018.

Times of India (2016, 20 December). Maharashtra shuts coaching centre run by college. http://timesofindia.indiatimes.com/city/mumbai/State-shuts-c oaching-centre-run-by-collegeStatetells-college-to-shut-IIT-prep-centre/articleshow/56074055.cms, accessed 1 January 2018.

Times of India (2017, 28 April). HRD Ministry puts plan for common engineering entrance exam on hold. http://timesofindia.indiatimes.com/home/education/news/hrd-ministry-puts-plan-for-commonengineering-entrance-exam-on-hold/articleshow/58415160.cms, accessed 1 January 2018.

Verger, A., Fontdevila, C. \& Zancajo, A. (2016). The privatization of education: A political economy of global education reform. New York: Teachers College Press.

Ward, S. (2013). Education policy and the marketization of education. In S. Ward (Ed.), A student's guide to education studies (pp.3-11). New York: Routledge.

Zhan, S., Bray, M., Wang, D., Lykins, C., \& Kwo, O. (2013). The effectiveness of private tutoring: Students' perceptions in comparison with mainstream schooling in Hong Kong. Asia Pacific Education Review, 14(4), 495-509.

Zhang, W. (2014). The demand for shadow education in China: Mainstream teachers and power relations. Asia Pacific Journal of Education, 34(4), 436-454.

Zhang, W., \& Bray, M. (2017). Micro-neoliberalism in China: Public-private interactions at the confluence of mainstream and shadow education. Journal of Education Policy, 32(1), 63-81. 